International Journal of Current Aspects in Finance, Banking and Accounting, Volume 2, Issue 2, 2020 PP 34-46, ISSN 2707-8035

[i]CAB

\title{
Influence of Financing on Performance of Small and Medium Women Owned Enterprises in Kwale County, Kenya
}

\section{Obiria Lenard Osiemo ${ }^{1}$, James Rugami Maina²}

${ }^{1}$ Student, Master of Business Administration, (Entrepreneurship), Kenyatta University, Kenya

${ }^{2}$ Lecturer, Business Administration Department, Kenyatta University, Kenya

\begin{abstract}
Studies done by researchers around the world show women are in entrepreneurship in major towns and rural areas of Africa. Financial institutions have developed various products to boost their entrepreneurial spirit together with government support programmes with an aim to avail credit and increase the success rate of women owned businesses. The study sought to determine the influence of capital on performance of small and medium enterprises owned by women entrepreneurs. The main variables under focus included; access to capital, working capital structure, capital affordability and government finance programs. The study will fill a research gap as there is no known study to have been done in Kwale county. The theoretical framework forming the basis of the study consisted of; resource-based theory, dynamic trade off theory and access to capital theory. A comprehensive literature review was given for each variable and their relationships highlighted. The study adopted a descriptive research design, a population of 2000 and a sample of 600 SME owners. Furthermore, the study used questionnaires for data collection that were hand delivered to respondents after validity and reliability through pilot testing techniques. Data collected was coded, sorted and analyzed by use of simple regression model with the help of Statistical Package for Social Sciences application. The study was conducted in line with ethical requirements by seeking permissions from the university and government institutions before commencement of the study. Data from 501 respondents was analysed representing 83.5\% of the sample. The results indicated that access to capital, capital affordability, working capital structure and government finance programs had a positive influence on performance of women owned SMES. The study concluded that for women entrepreneurs to perform well in their business, efforts should put in place to ensure capital is made accessible, affordable while enlightening them on what alternatives sources of capital are available; whether from the government or private sector, for better working capital structure. Finally, the study recommended that studies should be conducted on influence of knowledge, skills and management styles on the performance of women owned SMES in Kwale County.
\end{abstract}

Key Words: Access to Capital, Asset Structure, Capital Affordability, Government Finance Programs, Financing

DOI: $10.35942 /$ ijcfa.v2i2.130

Obiria, L., \& Maina, J. (2020). Influence of Financing on Performance of Small and Medium Women Owned Enterprises in Kwale County, Kenya. International Journal of Current Aspects in Finance, Banking and Accounting, 2(2), 34-45. https://doi.org/10.35942/ijcfa.v2i2.130 
International Journal of Current Aspects in Finance, Banking and Accounting, Volume 2, Issue 2, 2020 PP 34-46, ISSN 2707-8035

[iJCAB

\section{Introduction}

Across the globe small and micro businesses are viewed as a preserve of people who are less fortunate or with less income. Most of such small businesses are characterized by low use of technology, financial investment and less skilled human resources, (Aguru \& Emeti, 2014). Due to growing unemployment for the youth who graduate from schools, governments are now viewing small business as an alternative of employment creation, (Akindele \& Odusina, 2015). Apart from employment creation, SMEs are seen as the beginning of mass production and creation of business leaders through practises, although the success rate is low in Africa unlike their counterparts in the United States of America and the United Kingdom, (Akindele \& Odusina, 2015). As the interest in small and micro enterprises among the population, it has been observed over time that men are more engaged. Women are fewer in SMEs which is attributed to African culture which alienate the woman from the workplace. The few women owned businesses are struggling financially due to insufficient credit, (Aktas, Croci and Petmezas, 2015). Due to poor credit access, women find it difficult to expand their business to serve a big customer base and earn high incomes like their male counterparts. Baños-caballero, Garcia-Tennel and Martinez-Solano (2014) are of the view that, hindrances are even high in Sub-Saharan Africa because they do not have collaterals that they can use as security for loans. Family properties i.e land and animals belong to the male members of the family and the females in the family are not allowed to inherit anything.

The government of Kenya has been in the forefront in promoting women entrepreneurs' accessibility to affordable and sufficient credit (Gichuki, Mulu-Mutuku \& Kinuthia, 2014). The creation of Women Enterprise fund (WEF), Uwezo fund and enactment of Public Procurement and Disposal Preference and Amendment Regulations Act of 2013 was intended to achieve this objective (Gichuki, Mulu-Mutuku \& Kinuthia, 2014). The WEF was established in August 2007 as a semi-autonomous Government Agency through Legal Notice No 147, Government Financial Management Regulations. It was a flagship project of Kenya's Vision 2030 and government's commitment to the realization of the Millennium Development Goals (MDG) on gender equality and women empowerment (Kiraka, Kohia and Katwalo, 2013). These initiatives adopted by the national government, county government and development partners is aimed at ensuring accessibility of women to credit and other financial assistance that will drive the success rates of women owned businesses to a new level. This concept can be defined as resources in monetary form that are necessary for daily business operations. It can further be defined as the compositions of resources and borrowed finances that a firm has, (Iqbal, 2015). To effectively manage the balance between equity and borrowing, managers have to a find a working ratio so that they do not lead the company into bankruptcy. This does not mean for example that, over borrowing leads to bankruptcy, however, what matters is the utilization of the borrowed finances, if invested well, they can lead to better perfomance and growth of the business, (Hailu \& Venkateswarlu, 2016).

Drucker (2014) states that, businesses in the small and micro categories have a challenge in balancing equity and debt. Many people especially borrow money from financial institutions and fail to put the money in better use and instead misappropriate. As a result of poor financial knowledge on how to effectively use the acquired credit, many women in entrepreneurship misappropriate the finances and lose their properties through auctioneers when they fail to service their debts. In the recent past, financial institutions have developed training programmes with a need to equip small business owners with the necessary skills that they can use to effectively manage their finances in such ways as; debt collection from sales made on credit and loan servicing (Claudia, 2013). Charitou, Elfani and Lois (2016) found that, male entrepreneurs perform better in 
International Journal of Current Aspects in Finance, Banking and Accounting, Volume 2, Issue 2, 2020 PP 34-46, ISSN 2707-8035

[IJCAB

business than their female counterparts. They made a comparison on the number of female owned enterprises versus the male owned enterprise during their study and established a wide gap between the two. Furthermore, they realised that, the few women owned enteprises had low chances of success and were small in size with few resources and low sales volume. The major reason that women indicated for underperformance as compared to their male counterpart was lack of credit that enabled them to full acquire all the resources they needed to effectively manage their businesses. In another study (Maengwe \& Otuya, 2015) established that, there is gender bias when giving out credit to women by some financial institutions which arise due to religion and belief that men are better positioned to succeed in business than women.

Saparito et al. (2013) did a comparison on trust levels that leaders of financial institutions had towards men and women using a population of 696 of firm owners and bank managers which established that, financial leaders had more interest on males than women. They indicated they felt more comfortable giving credit to males as compared to females. They reasons for such levels of high trust was attributed to good male credit history and willingness to take risks that yield high returns. The study revealed that, men had a higher understanding of financial management as compared to female who lack knowledge on budgeting, savings and investments. The study also revealed that shortages of assets and multifarious socialization trends contribute to negative performance of women entrepreneurs in MSEs. Karadag (2015) states that women are overloaded with business and family responsibilities and may not have time to join business organization and this automatically limits the women entrepreneurs' wing of exploitation. Lusayi, Simiyu and Robert (2014) are of the view that, women have a social burden of ensuring their families are well taken care of unlike their male counter parts. As such, they tend much of the little resources on families and sometimes use resources in their business to fulfill family obligations. In addition to this, women entrepreneurs in developing countries continue to suffer from poor overall assets ownership, poor enforcement of financial rights and the existence of unequal inheritance rights and consequently poor access to community and social resources.

According to Makori and Jagongo (2013), women may be disadvantaged in their ability to raise finances, guarantee required for external financing may be beyond the scope of most women's personal assets and credit track record. Lack of capital is the greatest barrier for growth of handicraft women owned businesses in Kenya as they require money to buy the raw materials to make the handicrafts. Kwale is a county found at the south coast of Kenya. It is a county mostly inhabited by the coastal people and other people from across the country and the world at a large. It has some of the world-famous sand beaches, game reserves and rare earth mineral deposits. Within its major towns like Ukunda, businesses thrive however, most of the well-established businesses are owned by men as compared to women. Women run such business like, food kiosk, saloon, laundry, M-pesa, textiles enterprises which employ less than five employees. Most of the business run by women are owned by their husbands or hired by someone else. For those who own their business, they perform dismally and others forced to close shop after a short period of operation. Matuga sub-county is an electoral constituency in Kwale County. It has five wards that include; Tsimba, Golini, Waa, Tiwi, Kubo south and Mkongani. It is the host to Kwale County headquarters and national government county office headquarters. The sub-county is also a host to medical technical training institute and government training institute. In terms of business, it's the most active sub-county as it is rich in agriculture production in the fertile Shimba hills farms that receive good rains in a year. Blessed with the Shimba hills game reserve, it's a tourist hotspot for wild-life lovers and sports men. It is also located a short distance to Mombasa in a way that, 
International Journal of Current Aspects in Finance, Banking and Accounting, Volume 2, Issue 2, 2020 PP 34-46, ISSN 2707-8035

[IJCAB

residents work within the city by day and spend the night with their families. It has a high population and vibrant business environment that has attracted many small-scale traders. Msambweni sub- County is home to Ukunda, the largest urban centre in Kwale County. It is home to world renowned tourist sites of Diani which boast one of the best sand beaches in the world. It also hosts a Medical training college, a county referral hospital, a mining company and a sugarcane processing firm. On other hand, Kinango is a majorly rural sub county and receives less than enough rainfall. It therefore depends on the neighboring sub counties for its people's sustenance.

\section{Sstatement of the problem}

Overtime, it has been observed that the perception towards business varies with gender. Women view business differently and this has a direct influence on how they run their businesses, manage their income and see opportunities that are of high risk or places that keep them a distant from the families, (Jindrichovska, 2013). In most case scenarios, the failure rate among women owned enterprises is high as compared to men owned enterprises. The motives also vary, as men venture into business with a purpose to create more wealth, women are inclined on profit and aspire for intrinsic motives (Gul, Khan \& Raheman (2013). The topic of women owned enterprises has gained significant interest from researchers who seek to establish role of micro-credit on perfomance of women owned businesses. For instance; Ahiabor (2013) conducted a study to assess the impact of micro-finance on SMEs in Ghana, using a simple random sampling technique for a sample of 70 SMEs and 30 MFIs the study revealed that there exist awareness among SME owners on MFI products and the contributions it has made in SME growth, however, the study did not focus on women entrepreneurs: Yusuf (2014) examined effects of micro-credit on small scale enterprises in Osun-state Nigeria, adopting a descriptive statistical method and a sample of 120 SME owners and 105 credit users, it established that loan repayment, family size and experience were key determinants in business turn-over. The study adopted a general approach in SMEs and did not focus on women entrepreneurs; Ochola (2013) examined the effect of finance on productivity, profitability, growth and expansion of women owned enterprises in Kisumu, by use of clustering, simple and random purposive and random sampling on a sample of 341 women registered businesses, the study revealed that sufficient micro-financing greatly affect profitability, productivity, growth and expansion, the study failed in looking at working capital and women owned SMEs; Gichuki, Mulu-Mutuku and Kinuthia (2014) examined the challenges facing microSMEs in accessing credit facilities in Kangemi Harambee Market, by use of descriptive research design and a sample of 241 MSEs the study established that collaterals are the key challenges to access of credit, however, the study did not look into government financing programs that offer credit to women owned businesses. Though the said studies dwelt on performance, they were done in in different contextual settings and did not capture all the variables under study in this paper; furthermore, the research did not find any study that has been conducted on the influence of capital on Women owned enterprises in Kwale County, a gap that the study sought to fill.

\section{Objectives of the study}

The general objective of the study is to determine the influence of capital on performance of small and medium enterprises owned by women entrepreneurs in Matuga sub-county

The specific objectives of the study were;

i) To establish the effect of access to capital on the performance of women owned enterprises in Matuga sub-county. 
International Journal of Current Aspects in Finance, Banking and Accounting, Volume 2, Issue 2, 2020 PP 34-46, ISSN 2707-8035

[IJCAB

ii) To explore the effect of asset structure on the performance of women owned enterprises in Matuga sub-county.

iii) To establish the effect of capital affordability on the performance of women owned enterprises in Matuga Sub-county.

iv) To investigate the impact of government finance programs on the performance of women owned enterprises in Matuga sub-county.

\section{Theoretical review}

\subsection{Access to Capital Theory}

This theory is based on the assumption that knowledge gap-debt is as a result of poor understanding of the various financial services offered by financial institutions, (Michello \& Wanorie, 2015). This is also associated to the fact that access to credit is still a problem to many small and micro enterprise sectors. For big businesses, it's easy to access capital because they have the required collateral and assets base they can use to secure financing from financial institutions, (Thapa, 2013). Small and medium enterprises are the businesses mostly affected by taxation policies in most countries (Wasiuzzaman, 2015). Due to their misunderstanding on tax compliance, the find it difficult to understand the different taxes levied by different authorities and the exemptions that exist which would lead to more profits. Another issue is the fact that, SMEs do not seek to understand the terms and conditions by financial institutions for instance the interest charged, (Ukaegbu, 2014). The relevance of this theory to this study is that it helps women entrepreneurs understand how to identify the capital gap and means in opportunities that exist in financial and government institutions to help them acquire the needed capital.

\subsection{Resource-Based view}

Penrose (1959) is accredited for the development of the resource based theory and provides an explanatory logic to unravel casual links among resources, capabilities and competitive advantage which contributes to a resource based theory of competitive advantage. Penrose (1959) further maintains that; firms can create economic value not due to mere possession of resources but due to effective and innovative management of resources. Furthermore, the theory is of the view that, the success and uniqueness of a company as compared to its competitors is as a result of the resources that it has in terms of qualified human capital, machineries, raw materials and finances at its disposal, (Nobanee \& Abraham, 2015). Availability of enough finances for example gives a business an edge over others as it is in a position to venture to new businesses, fund its operations and enjoy other economies of scale available in the industry, (Ochanda, 2014). Of importance as explained in this theory is for business owners to manage the growth of their businesses and being in a position to tell when their businesses are maing profits or losses. Growth and good perfomance of businesses can best be achieved with availability of sufficient resources, (Silva, 2017). Sufficient resources also enable a firm have an edge over its competitors as it gives the firm an upper hand and abilities to source for what it needs to make the business a success, (Stephen \& Lucy, 2013). In relation to the study, the theory helps in explaining the usefulness of understanding the firm's capital structure with an aim to improve women owned SME perfomance by using more of equity than borrowing from bans which might be a challenge to repay. 
International Journal of Current Aspects in Finance, Banking and Accounting, Volume 2, Issue 2, 2020 PP 34-46, ISSN 2707-8035

\section{[i]CAB}

\subsection{Dynamic Trade-off Theory}

The dynamic trade-off theory is set on the belief that; as a result of insufficient information in the market and high expenses of carrying out business operations business leaders are willing to go an extra mile and allow excess capital ratios in a controlled manner in the event of uncertainties (Jean, 2008). Such situations are monitored and their effect on perfomance gauged, when there are large disparities from the expected outcome, necessary steps are taken to streamline business operations, (Tauringana and Adjapong, 2013). In a good financing decision, businesses are expected an amount of money that they easily manage and service with less difficulties, (Ray, 2014). According to Pais and Hama (2015), small businesses are expected to borrow little and avoid unnecessary borrowing that is the cause of many business failures. For large businesses, their borrowing is also supposed to be regulated and be aware of the changes that are happening in the economy such as inflation and rise in in interest rates, unstable currencies that might affect the servicing of loans. The theory is useful as it calls for women entrepreneurs to balance between debt and equity and affordability of working capital in financing of the business while keeping the possible benefits to be realized at a given time.

\section{Conceptual Framework}

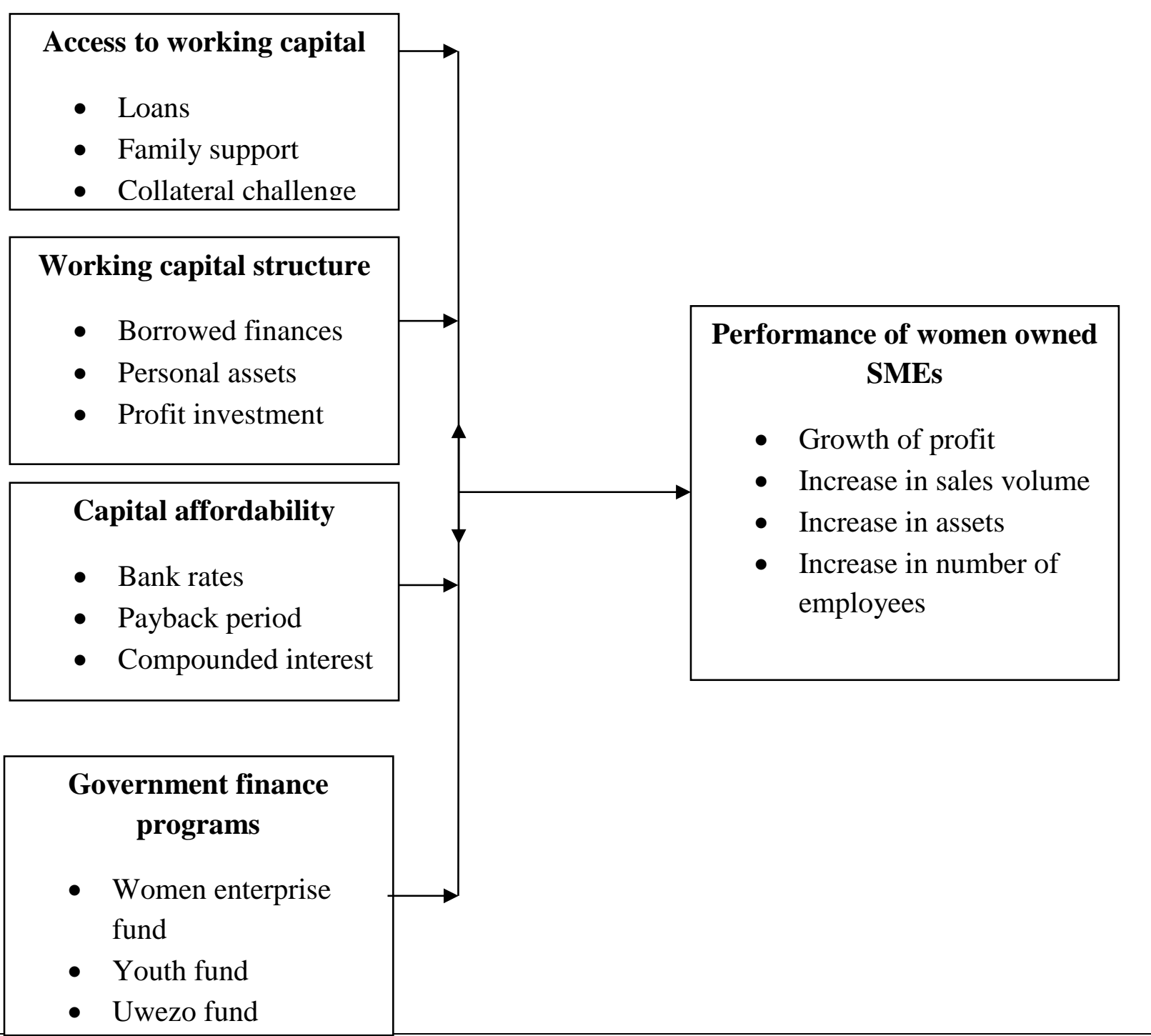


International Journal of Current Aspects in Finance, Banking and Accounting, Volume 2, Issue 2, 2020 PP 34-46, ISSN 2707-8035

[IJCAB

\section{Figure 1: Conceptual framework}

\section{Source: Researcher (2020)}

The conceptual framework contains the independent and dependent variables. The independent variables are the ones that cause change on other variables. The independent variables are; access to working capital, working capital structure, capital affordability and government finance programs.

\section{Research Methodology}

The study adopted a descriptive research design with an aim of providing a thorough investigation and is appropriate in this study since it describes what happens and the researcher reports only what will be happens as pertains to the study. The study engaged a total of 2000 Women owned enterprises operating in Kwale County. Stratified random sampling was used to achieve desired representation from various subgroups in the population. According to Mugenda and Mugenda (2003), stratified random sampling involved selecting subjects in such a way that the existing subgroups in the population are more or less reproduced in the sample. According to Mugenda and Mugenda (2003) a sample size between $10 \%$ and $30 \%$ is considered a sufficient sample size. The study used a sample of 600 which is $30 \%$ of the target population for all women owned enterprises across the sectors in Kwale County. The primary tool for data collection was questionnaires containing open ended and closed questions. Questionnaires were chosen because they are simple to administer and the respondents are able to answer them within their own time. Questionnaires were hand delivered to respondents and this was done to allow explanation of hard to understand questions. Data was analysed by use of regression models with the help of Statistical Package for Social Sciences (SPSS). A linear regression describes and evaluates the relationships between a given dependent variable and one or more independent variables, (Cooper \& Schindler, 2010).

\section{Data Analysis}

Regression analysis was used to model, examine, and explore the relationships between the dependent variable (performance of women owned SMEs in Kwale County) against the four independent variables (access to capital, affordability of capital, asset structure and government finance programs) used for the study.

\section{Table 1:Results of multiple Regression}

\begin{tabular}{|c|c|c|c|c|}
\hline Model & $\mathrm{R}$ & R Square & $\begin{array}{l}\text { Adjusted R } \\
\text { Square }\end{array}$ & $\begin{array}{l}\text { Std. Error of } \\
\text { the Estimate }\end{array}$ \\
\hline 1 & $.934^{\mathrm{a}}$ & .873 & .802 & .0312 \\
\hline
\end{tabular}

Source: Research Data (2019)

The four independent variables (access to capital, affordability of capital, asset structure and government finance programs) that were studied, explain $80.2 \%$ of the performance of women owned SMEs in Kwale County as represented by the adjusted R square. This therefore means that other factors not studied in this research contribute $19.8 \%$ of the performance of women owned SMEs in Kwale County. Analysis of Variance (ANOVA) was used to determine the linear relationship among the variables under investigation. Using this method, the sum of squares, 
International Journal of Current Aspects in Finance, Banking and Accounting, Volume 2, Issue 2, 2020 PP 34-46, ISSN 2707-8035

[IJCAB

degrees of freedom (df), mean square, value of $\mathrm{F}$ (calculated) and its significance level was obtained. The results are shown in Table 2.

Table 2: ANOVA

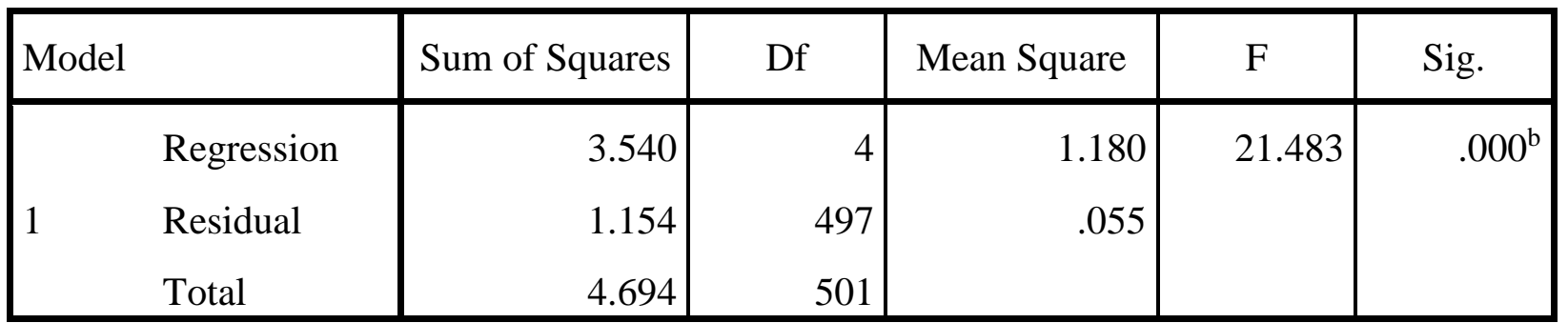

Source: Research Data (2019)

\section{Source: Research Findings}

From the data findings in table 2 above, the sum of squares due to regression is 3.540 while the mean sum of squares is 1.180 with 4 degrees of freedom. The sum of squares due to residual is 1.154 while the mean sum of squares due to residual is 0.055 with 497 degrees of freedom. The value of $F$ calculated is 21.483 and the significance value is 0.005 . The $p$ value is 0.000 . Since the $\mathrm{p}$ value is less than 0.05 it implies that the relationship is significant at $95 \%$ level of significance; the model is therefore significant for the study and prediction.

Table 3: Coefficient of Determination

\begin{tabular}{|c|c|c|c|c|c|c|}
\hline & & \multicolumn{2}{|c|}{ Unstandardized Coefficients } & \multirow{2}{*}{\begin{tabular}{|l}
$\begin{array}{l}\text { Standardized } \\
\text { Coefficients }\end{array}$ \\
Beta \\
\end{tabular}} & \multirow[b]{2}{*}{$\mathrm{t}$} & \multirow[b]{2}{*}{ Sig. } \\
\hline \multicolumn{2}{|c|}{ Coefficients } & B & Std. Error & & & \\
\hline \multirow[t]{5}{*}{1} & (Constant) & 0.540 & .645 & & 3.231 & .001 \\
\hline & Access to capital & 0.701 & .082 & 0.135 & 4.421 & .011 \\
\hline & $\begin{array}{l}\text { Affordability of } \\
\text { capital }\end{array}$ & 0.834 & .214 & 0.051 & 3.715 & .004 \\
\hline & \multirow{2}{*}{$\begin{array}{l}\text { Asset structure } \\
\text { Government } \\
\text { finance programs }\end{array}$} & 0.791 & .234 & 0.001 & 6.687 & 0.02 \\
\hline & & 0.693 & 0.542 & 0.013 & 7.012 & 0.03 \\
\hline
\end{tabular}

The established regression equation by the study was $\mathrm{Y}=0.540+0.701 \mathrm{X}_{1}+0.834 \mathrm{X}_{2}+0.791 \mathrm{X}_{3}$ $+0.693 \mathrm{X}_{4}$, Where $\mathrm{Y}=$ Performance of women owned SMEs in Kwale County, $\mathrm{X}_{1}=$ Access to capital, $\mathrm{X}_{2}=$ Affordability of capital, $\mathrm{X}_{3}=$ Asset structure, $\mathrm{X}_{4}=$ Government finance programs. From the above regression model, holding access to capital, affordability of capital, asset structure and government finance programs constant performance of women owned SMEs in Kwale County would be 0.542 . As shown in table 4.11 , access to capital, affordability of capital, asset structure and government finance programs had a positive and significant effect on the performance of performance of women owned SMEs in Kwale County as indicated by beta values. The relationships $(\mathrm{p}<0.05)$ are all significant with access to capital $(\mathrm{t}=4.421, \mathrm{p}<0.05)$, affordability of capital $(\mathrm{t}=3.715, \mathrm{p}<0.05)$, asset structure $(\mathrm{t}=6.687, \mathrm{p}<0.05)$ and government finance programs $(\mathrm{t}=7.012, \mathrm{p}<0.05)$. Access to capital was found to have a greater $(83.5 \%)$ on the 
International Journal of Current Aspects in Finance, Banking and Accounting, Volume 2, Issue 2, 2020 PP 34-46, ISSN 2707-8035

[IJCAB

performance of SMEs in women owned SMEs in Kwale County compared to affordability of capital $(79.2 \%)$, asset structure $(70.1 \%)$ and government $(69.4 \%)$.

\section{Conclusion}

The study concludes that access to capital, affordability of capital, working capital structure and government finance programs had a positive influence on performance of women owned enterprises. On access to capital the study found out that most women owned SMEs in Kwale County obtained their capital from owners' savings, bank loans and contributions from family and friends. However, majority of them could not access bank loans due to lack of necessary collateral. On affordability of capital, the study found out that most SMEs would not take up banks loans on offer because of high interest rates. Moreover, short payback period and penalties in case of default contributed immensely to unaffordability of capital. Thus many women owned SMEs experienced difficult in loan repayment and therefore this hindered subsequent loan financing for their businesses. On working capital structure, it was found that most women owned SMEs in kwale county had a mix of borrowing, personal savings and profit ploughed back from business as their working capital mix. Having a good working capital structure mix contributed to the overall performance of women owned SMEs in Kwale County. A good working capital structure ensures that SMEs are able to meet their needs and expectations of customers. On government finance programs, the study found out that some women owned SMEs in Kwale County had used these sources and it had a significant positive influence on their performance. However, it was noted that lengthy acquisition procedures and prerequisite requirements posed a challenge in accessing these facilities.

\section{Recommendations}

The study recommends that the SMEs in Kwale County should seek access to cheaper forms of capital for their business operations. They should also lobby both the county government of Kwale and the national government for assistance in accessing cheaper forms of business financing. The study further recommends that for the SMEs in the County government of Kwale to achieve their vision they should align their annual goals by embracing the best working capital structure that helps promote growth and profitability. The study also recommends that women owned SMEs in Kwale County should lobby both the county government and the national government to come up with policies that support SME growth such as affordability of capital. The study recommends that women owned SMEs in Kwale County should identify and seek more government finance programs such as women enterprise fund, youth fund and Uwezo fund that can provide cheaper finances to help further cost reduction in their operations in order to enhance SMEs performance. It is also recommended that women owned SMEs lobby the National government to remove lengthy acquisition procedures and numerous requirements to make it accessible.

\section{REFERENCES}

Agwu, M. O., \& Emeti, C. I., (2014).Issues, challenges and prospects of small and medium scale enterprises (SMEs) in Port-Harcourt city. European Journal of Sustainable Development, 3(1), 101-114.

Akindele, J., \& Odusina, O., (2015). Working capital Management and firm profitability: Evidence from Nigeria Quoted companies. Journal of Finance and Accounting, 6(7), 148-153.

Aktas, N., Croci, E., \& Petmezas, D., (2015). Is working capital management value-enhancing? Evidence from firm performance and investments, Journal of Corporate Finance, 30, 98113 
International Journal of Current Aspects in Finance, Banking and Accounting, Volume 2, Issue 2, 2020 PP 34-46, ISSN 2707-8035

\section{[IJCAB}

Baños-Caballero, S., García-Teruel, P. J., \& Martínez-Solano, P., (2014).Working capital management, corporate performance, and financial constraints, Journal of Business Research, 67(3), 332-338.

Charitou, M. S., Elfani, M., \& Lois, P., (2016).The effect of working capital management on firm's profitability: empirical evidence from an emerging market, Journal of Business \& Economics Research (Online), 14(3), 111

Claudiu, B. (2013). The Effect of Working Capital on Profitability: Evidence from Romania, Ovidius University Annals, Series Economic Sciences, 13(1).

Cooper D. and Schindler, P. (2010).Business Research Methods, McGraw-Hill, United Kingdom

Drucker, P. (2014).Innovation and Entrepreneurship: Practice and Principles, Routledge Classics.

Enqvist, J., Graham, M. \& Nikkinen, J., (2014).The impact of working capital management on firm profitability in different business cycles: Evidence from Finland. Research in International Business and Finance, 32, 36-49.

Gichuki, C. N., Mulu-Mutuku, M., \& Kinuthia, L, N. (2014).Performance of women owned enterprises accessing credit from village credit and savings associations in Kenya. Journal of Global Entrepreneurship Research,

Gul, S., Khan, M. B., Raheman, S. U., Khan, M. T., Khan, M., \& Khan, W. (2013). Working capital management and performance of SME sector, European Journal of Business and management, 5(1), 60-68.

Hailu, A. Y., \& Venkateswarlu, P., (2016). Effect of working capital management on firm's profitability evidence from manufacturing companies in Eastern, Ethiopia, Int. J. Appl. Res, 2, 643-647

Hassan, I.B., \& Mugambi, F (2013).Determinants of Growth for Women Owned and Operated Micro Enterprises: The Case of Garissa, Kenya, International Journal of Business and Commerce, 2(7), 45.

Iqbal, J. (2015). Impact of working capital management on profitability of the food and personal care products sector in Pakistan (Doctoral dissertation, The Islamia University of Bahawalpur).

Jindrichovska, I. (2013). Financial management in SMEs, European Research Studies Journal, 16(4), 79-96

JO Maengwe1 and WI Otuya (2015), A Critical Review on Micro-financing of Small Businesses in Kenya, Pyrex Journal of Business and Finance Management Research

Kamunge, M. S., Njeru, A., \& Tirimba, O. I., (2014). Factors affecting the performance of small and micro enterprises in Limuru Town Market of Kiambu County, Kenya, International Journal of Scientific and Research Publications, 4(12), 1-20.

Karadag, H. (2015). Financial management challenges in small and medium-sized enterprises: A strategic management approach. EMAJ: Emerging Markets Journal, 5(1), 26-40.

Kinyua, A. N. (2014). Factors affecting the performance of Small and Medium Enterprises in the Jua kali sector in Nakuru Town, Kenya. Journal of Business and Management, 6(1), 5-10.

Kiraka, R.N., Kobia M., \& Katwalo A M (2013).Micro, Small and Medium Enterprise Growth and Innovation in Kenya: A case study on the Women Enterprise Fund. Investment Climate and Business Environment Research Fund, 28-82.

Kothari (2010) Research Methodology; Methods and Techniques, $2^{\text {nd }}$ Revised Edition, New Age International Publishers, New Delhi 
International Journal of Current Aspects in Finance, Banking and Accounting, Volume 2, Issue 2, 2020 PP 34-46, ISSN 2707-8035

iJCAB

Kothari C. R. (2004).Research methodology: methods and techniques (2nd Ed.). New Delhi: New Age International limited.

Kumar (2005), Research Methodology: A Step by Step Guide for Beginners, (2nd Ed.). New Delhi: Sage Publication.

Lusayi N, G, Simiyu N, and Robert W, W (2014).Factors Influencing Access to Debt Finance by Micro and Small Enterprises: A Case of Chwele Township, Bungoma County, Jomo Kenyatta University of Agriculture and Technology, Kenya.

Makori, D. M., \& Jagongo, A., (2013).Working capital management and firm profitability: Empirical evidence from manufacturing and construction firms listed on Nairobi securities exchange, Kenya. International Journal of Accounting and Taxation, 1(1), 1-14.

García-Teruel, P. J., \& Martínez-Solano, P., (2014).Trade credit and SME profitability, Small Business Economics, 42(3), 561-577

Mbiti F, M., Elegwa M, Dr. Joseph M \& Dr. Dorothy K (2015), the Influence of Access to Credit on Growth of Women- Owned Micro and Small Enterprises in Kitui County, Kenya, Public Policy and Administration Review.

Mbugua S. K, Dr. Agnes N, Ondabu I. T(2014), Factors Affecting the Performance of Small and Micro Enterprises in Limuru Town Market of Kiambu County, Kenya, Mount Kenya University- Hargeisa Campus Somaliland.

Michello, F. A., \& Wanorie, T. O., (2015).Analyzing the Effect of Working Capital Management on the Profitability of Small Size US Healthcare Companies, International Research Journal of Applied Finance, 6(5), 394-406.

Mugenda and Mugenda (2003) Research Methods: Quantitative and Qualitative approaches, Nairobi: Acts Press.

Mutua Mathuva, D. (2014). An empirical analysis of the determinants of the cash conversion cycle in Kenyan listed non-financial firms. Journal of Accounting in Emerging Economies, 4(2), 175-196

Mwangi, L. W., Makau, M. S., \& Kosimbei, G., (2014). Relationship between capital structure and performance of non-financial companies listed in the Nairobi Securities Exchange, Kenya. Global Journal of Contemporary Research in Accounting, Auditing and Business Ethics, 1(2), 72-90.

Nobanee, H., \& Abraham, J., (2015). Current assets management of small enterprises, Journal of Economic Studies, 42(4), 549-560

Ochanda, M. M. (2014). Effect of financial deepening on growth of small and medium-sized enterprises in Kenya: A case of Nairobi County. International Journal of Social Sciences and Entrepreneurship

Oluoch, J. O. (2014). An Assessment Of The Impact Of Working Capital Management Practices On The Performance Of Small And Medium Enterprises: A Survey of SMEs in Eldoret Central Business District (Doctoral dissertation, Kisii University).

Orobia, L. A., Byabashaija, W., Munene, J. C., Sejjaaka, S. K., \& Musinguzi, D. (2013). How do small business owners manage working capital in an emerging economy? A qualitative inquiry, Qualitative Research in Accounting \& Management, 10(2), 127-143

Pais, M. A., \& Gama, P. M. (2015).Working capital management and SMEs profitability: Portuguese evidence. International Journal of Managerial Finance, 11(3), 341-358.

Penrose, E. T. (1959), the theory of the growth of the firm, New York: John Wiley

Ray, K. K. (2014). Efficiency of working capital management and profitability: A case of Hindalco, Review of Knowledge Management, 4(1/2), 19. 
International Journal of Current Aspects in Finance, Banking and Accounting, Volume 2, Issue 2, 2020 PP 34-46, ISSN 2707-8035

\section{[IJCAB}

Saglam, N., Kagitci, A., \& Buyukipekci, S., (2016).Relationship between Working Capital Management and Profitability in Turkey Industrial Listed Companies, Journal of Modern Accounting and Auditing, 12(3), 147-155.

Saparito, Patrick, Amanda E and Candida B (2013).Bank-firm relationships: Do perceptions vary by gender? Entrepreneurship: Theory and Practice, 37(4): 837-858.

Silva, M. F. C., (2017), Working capital management, performance and financial constraints: the case of German firms (Doctoral dissertation)

Spanish, M. Hassan, I.B \& Mugambi, F. (2013).Determinants of Growth for Women Owned and Operated Micro Enterprises: The Case of Garissa, Kenya, International Journal of Business and Commerce, 2(7), 45.

Stephen O. M, Lucy, G., (2013).The effects of capital budgeting techniques on the growth of micro-finance enterprises in Mombasa, International Journal of Science and Research (IJSR)

Tauringana, V., \& Adjapong, G., (2013).The relative importance of working capital management and its components to SMEs' profitability, Journal of Small Business and Enterprise Development, 20(3), 453-469.

Thapa, P. D. P. (2013). How does profitability get affected by working capital management in food and beverages industry?. Journal of Advanced Research in Management, 4(2 (8)), 79

Tran, H., Abbott, M., \& Jin Yap, C. (2017). How does working capital management affect the profitability of Vietnamese small-and medium-sized enterprises?. Journal of Small Business and Enterprise Development, 24(1), 2-11.

Ukaegbu, B. (2014). The significance of working capital management in determining firm profitability: Evidence from developing economies in Africa. Research in International Business and Finance, 31, 1-16.

Wasiuzzaman, S., (2015).Working capital and firm value in an emerging market. International Journal of Managerial Finance, 11(1), 60-79.

Yazdanfar, D., \& Öhman, P., (2015). Debt financing and firm performance: an empirical study based on Swedish data. The Journal of Risk Finance, 16(1), 102-118.

This is an open-access article published and distributed under the terms and conditions of (c) (†) \&

the Creative Commons Attribution 4.0 International License of United States unless otherwise stated. Access, citation and distribution of this article is allowed with full recognition of the authors and the source.

Authors seeking to publish with an Internationally Peer Reviewed Journals should consider https://www.ijcab.org/ by writing to the Editor at editor@ijicab.org or submitting online at https://journals.ijcab.org/journals/index.php. The articles must be quality and meet originality test.

$\frac{\text { IJCAB }}{\text { Publishing Group }}$ 